Reprod. Nutr. Dévelop., 1986, 26 (3), 767-775.

\title{
The influence of season and shade on oestrous behaviour, timing of preovulatory LH surge and the pattern of progesterone secretion in FFPN and Creole heifers in a tropical climate
}

\section{GAUTHIER (1)}

with the technical assistance of G. COULAUD and H. VARO

Station de Recherches zootechniques, I.N.R.A., Domaine Duclos, 97170 Petit Bourg, France.

Summary. The aim of this work was to study the duration of oestrous behaviour, timing of the LH surge and the progesterone pattern with and without shelter during January and again in July in FFPN and Creole heifers in a tropical environment. From days 21 to 28 after a synchronization treatment (progesterone + PMSG), ten Creole heifers and ten FFPN heifers were checked for oestrus and sampied for blood every $3 \mathrm{~h}$ to assay plasma $\mathrm{LH}$ levels and every day from that oestrus to the following one to assay plasma progesterone content.

Five heifers in each group were housed in a covered corral and five were exposed to the sun in a corral without shelter.

The mean duration of oestrus for all the heifers was $14.0 \mathrm{~h}$. There was a significant breed/season interaction : $21 \mathrm{~h}$ in July and $15 \mathrm{~h}$ in January for FFPN heifers. Sun exposure did not significantly affect the mean duration of oestrus.

The distribution of onset of heat with respect to time of day was not uniform : $29 \%$ of the oestruses began between 5 and 8 a.m. and $19 \%$ between 8 and 11 p.m.

The mean interval between onset of heat and maximal $\mathrm{LH}$ value $(3.58 \mathrm{~h})$ only varied significantly with the season $(1.6 \mathrm{~h}$ in January and $6.0 \mathrm{~h}$ in July; $\mathrm{P}<0.05)$ but was equivalent to those obtained by other authors.

The plasma progesterone levels of both breeds were lower than those described for cows in temperate countries and were lower for shaded FFPN heifers in January 12.8 $\mathrm{ng} / \mathrm{ml}$ ) than in July $(3.93 \mathrm{ng} / \mathrm{ml})$. The luteal phase was shorter in Creole (17.4 days) than in FFPN (18.8 days) animals and was shorter for these two breeds in January (17.2 days) than in July (19.0 days). Exposure to sun radiation eliminated the effects of season on these two parameters in heifers of both breeds.

\section{Introduction.}

The conception rate of "Frisonne Française Pie Noire " (FFPN) (Vivier, Michalet-Doreau and Grudé, 1975) and Creole (Gauthier and Xandé, 1982) cows

(1) Present address : Elevage bovin, I.N.R.A. Theix 63122 Ceyrat, France. 
in Guadeloupe varies widely with the season. Fertility is higher between December and April in FFPN cows and between August and December in Creole cows. Furthermore, exposure to sun has been shown to depress fertility in Holstein, Jersey, Guernsey and Brown Swiss cows (Roman-Ponce et al., 1977).

However, the mechanisms by which season of year and sun exposure negatively affect fertility have not yet been completely elucidated. A logical hypothesis is that these factors alter hormonal patterns and oestrous behaviour, thus interfering with the normal reproductive processes (Ortavant and Loir, 1978).

The aim of the present work was to study the effects of season and of shelter from the sun on the duration of oestrous behaviour, timing of the preovulatory $\mathrm{LH}$ surge and the pattern of progesterone during the following luteal phase.

\section{Material and methods.}

Ten Creole heifers and ten FFPN heifers were given a treatment in January and again in June to synchronize oestrus, as described by Chupin and Pélot (1978). Progesterone was first given, followed by prostaglandin and $400 \mathrm{IU}$ of PMSG. During both seasons the heifers were maintained at $100 \%$ of the nutrition requirements recommended by I.N.R.A.

On the day of PMSG injection, the heifers were divided into two equal groups, matched according to breed, age and weight. The first group, housed in a covered corral, was protected from direct sunlight, while the second group was housed in a corral without shelter.

Oestrus was detected when the heifer accepted to be mounted by a vasectomized or an androgenized cow (Signoret, 1975). The animals used for heat detection were changed every $12 \mathrm{~h}$. Twenty-one days after PMSG injection, heat detection was done every $6 \mathrm{~h}$ and, once the oestrus of the first female was detected, this frequency was increased to every $3 \mathrm{~h}$. These observations continued until day 28 after PMSG injection. The beginning of oestrus was considered to be mid-way between the time of the last observation (no oestrus) and the time that oestrous behaviour was first observed. The end of oestrus was similarly calculated, and the interval between these two times was considered to be the total duration of oestrus.

To study the $\mathrm{LH}$ pattern during the oestrous period, blood was collected every $6 \mathrm{~h}$, beginning 21 days after PMSG injection, and then every $3 \mathrm{~h}$ after the first female showed oestrus. To study the progesterone pattern, blood was collected at 8 a.m. every day from this oestrus to the following one (detected by two observations per day).

The blood samples were centrifuged immediately to obtain plasma which was then frozen and stored at $-20^{\circ} \mathrm{C}$ until assays.

A double antibody radioimmunoassay described by Pelletier (1972) was used to measure LH concentrations ; LH LER Reichert 1072-2 was the standard $11 \mathrm{ng}$ of LH LER 1072-2 = $2 \mathrm{ng}$ of LH NIH S1). Assay sensitivity was $0.2 \mathrm{ng} / \mathrm{ml}$, and the mean coefficient of variation was $10 \%$ for a value of $1 \mathrm{ng} / \mathrm{ml}$. 
A double antibody radioimmunoassay described by Yenikoye et al. (1981) was used to measure progesterone concentration. All the samples were measured in the same assay (sensitivity : $0.04 \mathrm{ng} / \mathrm{ml}$ ) ; the mean coefficients of variation were 8 and $13 \%$ for concentrations of 4 and $10 \mathrm{ng} / \mathrm{ml}$, respectively.

A preovulatory LH surge was considered to have occurred when we obtained a value greater than three times the basal level of a given heifer. The luteal phase of the progesterone pattern was fitted to a logistic function and the luteolytic phase to an exponential model (Yenikoye et al., 1981). This model was described by five biological parameters : $M=$ maximal progesterone level, $\mathrm{Tm}=$ time at which the rate of progesterone level increase was maximal, $\mathrm{Rm}=$ maximal rate of progesterone level increase, $\mathrm{DL}=$ duration of luteal phase, $\mathrm{Rd}=$ rate of progesterone level decrease at the beginning of the luteolytic phase. These parameters were estimated for each heifer by the least-squares method.

The influence of breed, season and shade on each parameter was studied by split-plot analysis of variance.

The climatic characteristics of the experiments are shown in table 1 .

\section{TABLE 1}

Means of maximal and minimal ambient temperature, total radiation, total rainfall and hours of daylight at the experimental site in January and July.

\begin{tabular}{lcc}
\hline & January & July \\
Maximal ambient temperature $\left({ }^{\circ} \mathrm{C}\right)$ & 28.7 & 30.8 \\
Minimal ambient temperature $\left({ }^{\circ} \mathrm{C}\right)$ & 22.9 & 24.5 \\
Total radiation $\left(M e g a j / \mathrm{m}^{2}\right.$ ) & 17.4 & 20.2 \\
Rainfall (mm) & 22.6 & 96.0 \\
Average hours of daylight (hours) & 11 & 13 \\
\hline
\end{tabular}

\section{Results.}

1) Oestrous behaviour. - In January, six of the Creole heifers and all the 10 FFPN heifers displayed oestrus, while in July eight heifers of each breed showed oestrus. Of the eight " non-oestral " heifers, only one ovulated at the end of the experimental period, as shown by progesterone levels.

The distribution of onset of heat with respect to time of day was not uniform (fig. $1 ; P<0.05$ ). Twenty-nine percent of the oestrous periods began between 5 and $8 \mathrm{a} . \mathrm{m}$. and $19 \%$ between 8 and $11 \mathrm{p} . \mathrm{m}$. These percentages are considerably higher than expected $(13 \%)$. In contrast, only $6 \%$ of the oestruses began between 11 p.m. and 5 a.m. There were no significant effects of breed, season or exposure to direct sunlight on this distribution.

The mean duration of oestrus for all the heifers was $14.9 \pm 6.3(\mathrm{M} \pm S D$ ). However, there was a significant breed/season interaction; the oestrus of FFPN heifers lasted longer in July $(21.0 \mathrm{~h})$ than in January $(15.3 \mathrm{~h} ; \mathrm{P}<0.05)$, while Creole heifers showed no seasonal difference (table 2). Overall, oestrus lasted longer in FFPN $(17.5 \mathrm{~h})$ than in Creole $(11.3 \mathrm{~h})$ heifers $(\mathrm{P}<0.01)$.

Reproduction, Nutrition, Développement, $n^{\circ}$ 3-1986. -2 


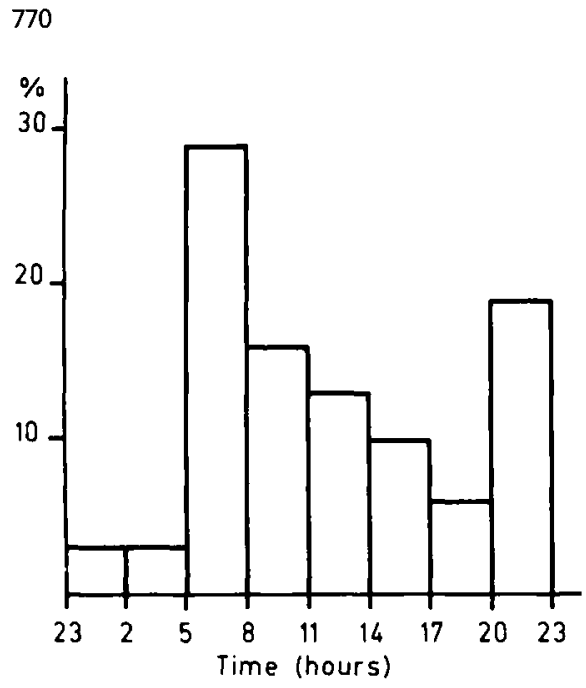

FIG. 1. - Distribution of the onset of oestrus behaviour.

\section{TABLE 2}

Duration of oestrus (hours) in FFPN and Creole heifers without and with shelter during January and July [m \pm sd. (number of females)].

\begin{tabular}{|c|c|c|c|c|}
\hline & \multicolumn{2}{|c|}{ January } & \multicolumn{2}{|c|}{ July } \\
\hline & Sun & Shelter & Sun & Shelter \\
\hline FFPN & $14.4 \underset{(5)}{ \pm} 1.3$ & $16.0 \pm 7.8$ & $20.4 \underset{(5)}{ \pm} 4.5$ & $22.5 \pm 6.0$ \\
\hline Creole & $10.5 \pm \frac{ \pm}{(2)} 6.4$ & $10.5 \underset{(4)}{ \pm} 5.2$ & $9.8 \underset{(4)}{ \pm} 3.0$ & $14.3 \underset{(4)}{ \pm} 6.0$ \\
\hline
\end{tabular}

2) $\mathrm{LH}$ surge (table 3). - During preovulatory $\mathrm{LH}$ surge, the mean plasma $\mathrm{LH}$ content of all the heifers increased from $1 \mathrm{ng} / \mathrm{ml}$ to $16.8 \mathrm{ng} / \mathrm{ml}$ (range : 3.4-35.4 $\mathrm{ng} / \mathrm{ml}$ ). The mean duration of this $\mathrm{LH}$ surge, ranging from 3 to $15 \mathrm{~h}$, was $7.7 \mathrm{~h}$.

The amplitude of the LH surge in Creole heifers was less than that of FFPN heifers $(12.6$ vs $19.9 \mathrm{ng} / \mathrm{ml} ; \mathrm{P}<0.01)$. However, its duration was the same, and neither season of the year nor exposure to sunlight had any effect on the duration or amplitude of this surge. The plasma LH concentration remained low in six of the eight heifers which did not show oestrous behaviour. The remaining two heifers exhibited an LH surge, but in one of these, ovulation did not follow the surge.

The mean interval from onset of oestrus to the maximal value of the $\mathrm{LH}$ surge was $3.58 \pm 4.67 \mathrm{~h}$ (range : -6 to $+12 \mathrm{~h}$ ). This interval did not vary significantly with breed or exposure to sunlight, but was shorter in January $(+1.6 \mathrm{~h})$ than in July $(+6.0 \mathrm{~h} ; \mathrm{P}<0.05)$.

The correlation between duration of heat and the interval between onset of heat and maximal level of LH surge was highly significant $(r=0.72 ; P<0.01)$. 
TABLE 3

Characteristics of preovulatory $\angle H$ peak in FFPN and Creole heifers bred in Guadeloupe.

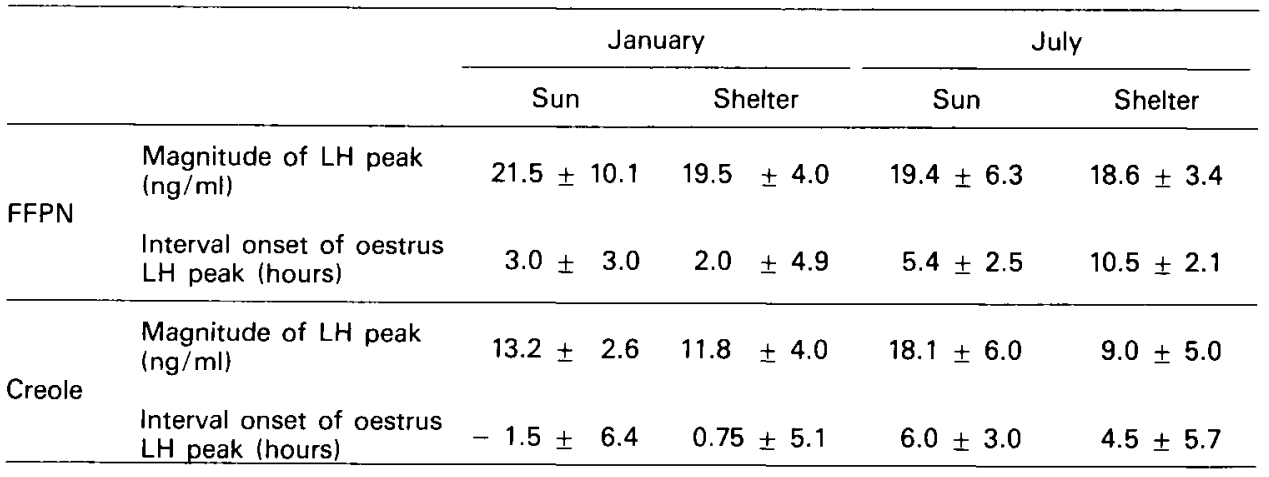

3) Progesterone secretion. - Plasma progesterone levels were very low (mean : $0.01 \mathrm{ng} / \mathrm{ml}$ ) on the day of oestrus in all the heifers that ovulated and increased with a maximal rate of $0.62 \mathrm{ng} / \mathrm{ml} /$ day on day 6 , reaching the maximal value of $3.53 \mathrm{ng} / \mathrm{ml}$. The average duration of the luteal phase was 18.2 days and the rate of progesterone decrease at the beginning of the luteolytic phase was $4.58 \mathrm{ng} / \mathrm{ml} /$ day.

Of the five parameters estimated, rate of progesterone decrease and time to maximal rate of increase were not affected by season, breed and/or exposure to direct sunlight. Breed significantly affected maximal rate of increase (Creole : $0.69 \mathrm{ng} / \mathrm{ml} /$ day ; FFPN : $0.56 \mathrm{mg} / \mathrm{ml} /$ day) and duration of the luteal phase (Creole : 17.4 days ; FFPN : 18.8 days), but not mean maximal level. Seasonal effect on duration of the luteal phase was significant in shaded Creole and FFPN heifers (January : 17.2 days ; July : 19.0 days), but this effect on mean maximal value (January : $2.80 \mathrm{ng} / \mathrm{ml}$; July : $3.93 \mathrm{ng} / \mathrm{ml}$ ) was significant only in FFPN heifers. Exposure to sunlight eliminated the effects of season on these two parameters since the results in January and July were very similar in unprotected heifers (table 4).

TABLE 4

Maximal progesterone concentration $(\mathrm{M}, \mathrm{ng} / \mathrm{ml}$ ) and duration of luteal phase (DL, days) in FFPN and creole heifers breeds in a tropical climate [mean $\pm s d . ; 1)=n^{\circ}$ of females].

\begin{tabular}{|c|c|c|c|c|c|}
\hline & & \multicolumn{2}{|c|}{ January } & \multicolumn{2}{|c|}{ July } \\
\hline & & Sun & Shelter & Sun & Shelter \\
\hline \multirow{2}{*}{ FFPN } & $M$ & $3.70 \pm 0.45^{b}$ & $2.84 \pm 0.46^{a}$ & $3.22 \pm 0.30^{b}$ & $3.93 \pm 0.25^{b}$ \\
\hline & $\mathrm{DL}$ & $19.06 \pm 2.31^{b}$ & $17.90 \pm \frac{15}{(5)} 1.26^{a}$ & $18.50 \pm 1.78^{b}$ & $20.16 \pm \frac{1}{(3)} 0.25^{b}$ \\
\hline \multirow{2}{*}{ Creole } & $M$ & $3.37 \pm 0.23^{b}$ & $4.21 \pm 0.81^{b}$ & $3.32 \pm 0.53^{b}$ & $3.92 \pm 0.72^{\mathrm{b}}$ \\
\hline & DL & $17.80 \pm \frac{ \pm}{(3)} 0.42^{a}$ & $16.28 \underset{(4)}{ \pm} 0.77^{c}$ & $17.55 \pm \frac{ \pm}{(4)} 1.42^{a}$ & $18.15 \pm 2.88^{a b}$ \\
\hline
\end{tabular}

(for a same parameter, values with the same superscript are not significantly different). 


\section{Discussion.}

This experiment demonstrates a diurnal variation in the onset of oestrus, consistent with the results of other authors in hot countries such as Kenya (de Vries, Osinga and Zeinstra, 1973) and Cuba (Solano, 1983). These data emphasize the importance of checking for oestrus early in the morning in such countries. Furthermore, the percentage of oestrus was not at its lowest during the hottest hours of the day, so high temperatures do not seem to suppress oestrous behaviour, as described by Ortavant and Loir (1978). The tropical climate of Guadeloupe did not decrease the length of oestrous behaviour which was comparable to that reported in temperate countries (Lemon et al., 1975 ; Schams et al., 1977) and longer than previously observed in other tropical climates (de Vries, Osinga and Zeinstra, 1973 ; Chenault et al., 1975). Contrary to what would be expected, oestrus was longer during the hot season than during the cool season in Guadeloupe. Thus, in our experimental conditions, either the temperature was not excessively high or the animals were sufficiently adapted and could overcome any major effect of climate on the expression of oestrous behaviour.

The mean duration and height of the preovulatory LH surge of the entire group was similar to that observed in temperate countries (Lemon et al., 1975 ; Schams et al., 1977), again showing that climate itself does not have a great effect on these parameters. However, the LH peak was lower for Creole than for FFPN heifers. The same results were obtained when Brahman and Hereford cows were compared in a hot climate (Randel, 1976). GnRH sensitivity was also shown to be lower in Bos indicus than in Bos taurus spayed heifers (Griffin and Randel, 1978); the close relationship of the Creole breed to Bos indicus breeds may explain the observed difference in the height of the LH peak.

The intervals between onset of oestrus and preovulatory $\mathrm{LH}$ peak have been reported to vary considerably, occurring $3 \mathrm{~h}$ before onset of oestrus (Swanson and Hafs, 1971) and $2.8 \mathrm{~h}$ (Chenault et al., 1975), $5.3 \mathrm{~h}$ (Randel, 1976) or $7.4 \mathrm{~h}$ after the onset of oestrus (Schams et al., 1977), without any clear evaluation of effects of climate and breed. This variation may be a result of the varying accuracy of oestrus detection (Lemon et al., 1975) or of a true seasonal effect, as described here. Thus, in our conditions, the interval between onset of oestrus and preovulatory LH peak is similar to other results in the literature.

The duration of the luteal phase and the mean maximal value of progesterone, showing a seasonal variation in shaded heifers, seem to be the most sensitive to environment and especially to temperature since, in the cool season (January), the effect of exposure to sunlight was similar to that in the hot season (July). FFPN heifers were more sensitive than Creole heifers. The effect of hot climatic conditions on the progesterone pattern is similar to that described by Abilay, Johnson and Madan (1975), who reported increased plasma progesterone levels in heifers exposed to heat stress in climatic rooms. However, the results of the current experiment together with those reported for the effect of hot season on progesterone in FFPN adult and lactating cows (Gauthier, 1983) are in opposition : in the heifers (this experiment), progesterone increased during the summer, while in the cows progesterone decreased, an effect which was eliminated by 
cooling with a sprinkler. Such a difference between heifers and lactating cows has also been reported by Johnson (1983) in Holsteins. It is reasonable to assume that the greater thermal stress in adult and lactating cows was due to milk production. Therefore, weak thermal stress in heifers could lead to an increase in progesterone concentration, while a severe thermal stress could lead to a decrease in progesterone concentration. The difference in response according to degree of thermal stress would explain the discrepancies between various authors, some of whom showed an increase in progesterone with temperature (Abilay, Johnson and Madan, 1975 ; Wolff-Vauaht, Monty and Foote, 1977) while others showed the opposite effect (Rosemberg et al., 1977, 1982 ; Rao and Pandey, 1982). In this experiment we could not avoid heifer age effect on these parameters because animal age increased between January and July. But this effect must be minor since Schams et al. (1977) failed to show any age effect on the progesterone pattern of cows.

The level of plasma progesterone was similar to that observed in a tropical climate (Roman-Ponce et al., 1981) but lower than reported in temperate countries (Yenikoye et al., 1981). These results show that the seasonal subfertility of cows in our conditions is more closely related to variations in progesterone secretion than to variations in oestrous behaviour or the appearance of the preovulatory LH peak. However, we need further information on the variation of the interval between the LH peak and ovulation and how it is affected by season.

Reçu en août 1985.

Accepté en janvier 1986.

Résumé. Influence de la saison et de l'exposition au soleil sur le comportement d'oestrus, le moment du pic préovulatoire de $\mathrm{LH}$ et l'évolution de la progestérone plasmatique chez des génisses FFPN et Créoles en climat tropical.

Le but de ce travail est d'étudier la durée du comportement d'œstrus, le moment du pic préovulatoire de $\mathrm{LH}$ et l'évolution de la progestérone plasmatique en janvier et juillet chez des génisses FFPN et Créoles abritées ou non du soleil en climat tropical. Entre les jours 21 et 28 suivant un traitement de maîtrise des cycles (progestagène + PMSG), 10 génisses Créoles et 10 FFPN subissent toutes les 3 heures une détection des chaleurs et un prélèvement sanguin pour doser la LH plasmatique. Puis tous les jours de l'cestrus détecté à l'cestrus suivant, ces animaux subissent également un prélèvement de sang dans le but d'apprécier les variations de la progestéronémie. Cinq génisses de chaque groupe étaient placées dans un parc couvert et les 5 autres dans un parc découvert et exposées au soleil.

La durée moyenne des chaleurs pour l'ensemble des animaux est de $14 \mathrm{~h}$. II existe une interaction significative entre la race et la saison sur ce paramètre : $21 \mathrm{~h}$ en juillet et $15 \mathrm{~h}$ en janvier pour les FFPN. L'exposition au soleil n'affecte pas significativement la durée de l'œstrus.

L'intervalle moyen début des chaleurs - valeur maximale de $\mathrm{LH}(3,58 \mathrm{~h})$ varie significativement avec la saison $(1,6 \mathrm{~h}$ en janvier et $6 \mathrm{~h}$ en juillet; $P<0,05)$.

Le niveau plasmatique moyen de progestérone est plus faible que celui décrit pour les vaches en zone tempérée et moins élevé pour les FFPN en stabulation couverte en janvier $(2,8 \mathrm{ng} / \mathrm{ml})$ qu'en juillet $(3,93 \mathrm{ng} / \mathrm{ml})$. La durée de la phase lutéale est plus courte pour les Créoles $(17,4$ jours) que pour les FFPN $(18,8$ jours) et plus courte pour les deux races en janvier (17,2 jours) qu'en juillet $(19,0$ jours). L'exposition des animaux au soleil supprime l'effet de la saison sur ces deux paramètres. 


\section{References}

ABILAY T. A., JOHNSON H. D., MADAN M., 1975. Influence of environmental heat on peripheral plasma progesterone and cortisol during the bovine estrous cycle. J. Dairy Sci., 58, 1836-1840.

CHENAULT J. R., THATCHER W. W., KALRA P. S., ABRAMS R. M., WILCOX C. J., 1975. Transitory changes in plasma progestins, estradiol and luteinizing hormone approaching ovulation in the bovine. J. Dairy Sci, 48, 709-717.

CHUPIN D., PÉLOT J., 1978. Fertility of dairy cows treated with implants, prostaglandin analog and PMSG. Theriogenology, 10, 307-311.

GAUTHIER D., XANDÉ A., 1982. Caractéristiques de reproduction d'un troupeau de vaches créoles élevées en zone tropicale. Ann. Zootech., 31, 131-138.

GAUTHIER D., 1983. Technique permettant d'améliorer la fertilité des femelles françaises frisonnes pie noire (FFPN) en climat tropical. Influence sur l'évolution de la progestérone plasmatique. Reprod. Nutr. Dévelop., 23, 129-136.

GRIFFIN J. L., RANDEL R. D., 1978. Reproductive studies of Brahman cattle : II. Luteinizing hormone patterns in ovariectomized Brahman and Hereford cows before and after injection of gonadotropin-releasing hormone. Theriogenology, 9, 437-443.

JOHNSON H. D., 1983. Heat stress effects on fertility and plasma progesterone, 419-431. P. CHEMINEAU, D. GAUTHIER, J. THIMONIER. In Coll. Reproduction des ruminants en zone tropicale, juin 1983, Pointe-à-Pitre. I.N.R.A., Publ., Versailles.

LEMON M., PELLETIER J., SAUMANDE J., SIGNORET J. P., 1975. Peripheral plasma concentrations of progesterone, oestradiol-17 $\beta$ and luteinizing hormone around oestrus in the cow. $J$. Reprod. Fert., 42, 137-140.

ORTAVANT R., LOIR M., 1978. The environment as a factor in reproduction in farm animals. IVe WId Conf. Anim. Prod., Buenos Aires, 1, 423-451.

PELLETIER J., 1972. Dosages radioimmunologiques de la LH plasmatique ovine et bovine, 237225. Les techniques endocrinologiques. Hôpital Saint-Antoine, In Coll. INSERM, Paris.

RANDEL R. D., 1976. LH and ovulation in Brahman, Branman $X$ Hereford and Hereford heifers. J. anim. Sci., 43, 100 (Abstr. 300).

RAO L. V., PANDEY R. S., 1982. Seásonal changes in plasma progesterone concentrations in buffalo cows (Bubalus bubalis). J. Reprod. Fert., 66, 57-61.

ROMAN-PONCE H., THATCHER W. W., BUFFINGTON D. E., WILCOX C. J., VAN HORN H. H., 1977. Physiological responses of lactating dairy cows to a shade structure in subtropical environment. J. Dairy Sci., 60, 424-430.

ROMAN-PONCE H., THATCHER W. W., WILCOX C. J., 1981. Hormonal inter-relationships and physiological responses of lactating dairy cows to a shade management system in a subtropical environment. Theriogenology, 16, 139-154.

ROSENBERG M., HERZ Z., DAVIDSON M., FOLMAN Y., 1977. Seasonal variations in post-partum plasma progesterone levels and conception in primiparous and multiparous dairy cows. $J$. Reprod. Fert., 51, 363-367.

ROSENBERG M., FOLMAN Y., HERZ Z., FLAMENBAUM I., BERMAN A., KAIM M., 1982. Effect of climatic conditions on peripheral concentrations of $L H$, progesterone and oestradiol-17 $\beta$ in high milk yielding cows. J. Reprod. Fert., 66, 139-146.

SCHAMS D., SCHALLENBERGER E., HOFFMAN B., KARG H., 1977. The oestrous cycle of the cow : hormonal parameters and time relationships concerning oestrus, ovulation and electrical resistance of the vaginal mucus. Acta endocrinol., 86, 180-192.

SIGNORET J. P., 1975. Nouvelle méthode de détection de l'œestrus chez les bovins. Ann. Zootech., 24, $125-127$.

SOLANO R., 1983. Distribucion y deteccion del estro en el gonado bovino. Momento de la ovulaccion, 315-325. In P. CHEMINEAU, D. GAUTHIER, J. THIMONIER. Coll. Reproduction des ruminants en zone tropicale, 8-10 juin, Pointe-à-Pitre. I.N.R.A. Publ., Versailles.

SWANSON L. V., HAFS H. D., 1971. LH and prolactin in blood serum from estrus to ovulation in Holstein heifers. J. anim. Sci., 33, 1038-1041. 
VIVIER M., MICHALET-DOREAU B., GRUDÉ A., 1975. La conduite d'un troupeau laitier intensif en zone tropicale humide (Antilles françaises). Nouv. Agron. Antilles-Guyane, 1, 307-321.

VRIES S. (de), OSINGA A., ZEINSTRA J., 1973. Length and frequency of oestrus in Friesian milking cows in Kenya. East Af. Agric. For. J., XXXIX, 176-179.

WOLFF-VAUGHT L. W., MONTY D. E., FOOTE W. C., 1977. Effect of summer heat stress on serum luteinizing hormone and progesterone values in Holstein Friesian cows in Arizona. Am. J. vet. Res., 38, 1027-1030.

YENIKOYE A., MARIANA J. C., LEY J. P., JOLIVET E., TEROUI M., LEMON-RESPLANDY M., 1981. Modèle mathématique de l'évolution de la progestérone chez la vache. Application et mise en évidence de différences entre races. Reprod. Nutr. Dévelop., 21, 561-575. 